\title{
自動車の自動運転システムの技術概要
}

\section{Technical Overview of Autonomous Driving System}

菅沼 直樹*1

\section{Naoki Suganuma}

\begin{abstract}
In recent years, the word "Autonomous vehicle" has come to be heard in various scenes including television, newspaper and other media. Autonomous vehicles are thought to have various advantages such as improvement of safety of cars, improvement of comfort of passengers, elimination of shortage of public transportation system. In this paper, we describe the outline of the technology required for autonomous driving system. In addition, we will outline the public road experiment which the authors' university is carrying out as the first trial at domestic university.
\end{abstract} Keywords: autonomous vehicle, perception, localization, path planning, human machine interface.

\section{1 緒言}

近年「自動運転」という言葉がテレビ，新聞等のメ ディアをはじめとして様々な場面で聞かれるようにな ってきた. 自動運転自動車は, 自動車交通の安全性向 上，搭乗者の快適性向上，公共交通機関不足の解消な ど，様々な効果が期待されている。

実は，この自動運転に関する研究の歴史は大変古く， 日本国内であれば 1960 年代から研究が開始されてい る[1]。またその後現在に至るまで, 様々な研究機関に おける研究開発や, 国家プロジェクトとしての研究プ ロジェクト[2]など様々な試みが行われてきた。一方, これまで研究開発されてきた自動運転システムの多く は，高速道路での走行を前提としたものがほとんどで あった。例えば磁気ネイル[3], 誘導ケーブルといった 設備をあらかじめ道路に敷設しておくことで自動運転 を実現する例や，高速道路であれば白線が連続して引 かれているためこれをカメラで読み取って自動運転を 行う例[4]など, インフラに強く依存した自動運転シス テムが開発されてきた。

一方，今まさに脚光を浴びている自動運転システム では,インフラに対する依存度がかなり下がっており， その結果として高速道路以外のいろいろな道で自動運 転が可能となってきた。一例として, 著者らの研究室

連絡先： 菅沼 直樹, 广920-1192 金沢市角間町, 金沢大 学新学術創成研究機構 自動運転ユニット,

e-mail: suganuma@staff.kanazawa-u.ac.jp

${ }^{* 1}$ 金沢大学
が国内の大学で初めての試み[5]として実施中の高齢 過疎化が進む地方の一般道路における自動運転自動車 の公道走行実証実験の例を示す。Fig. 1 は公道を自動 運転中の様子を示しており，安全のためハンドルに手 は添えているが，ステアリング，スロットル，ブレー キ, ウィンカーを含め自動車は完全にコンピュータで 制御されている。このような地方の道路ではインフラ にコストをかけることが難しいため, インフラに強く 依存した従来の自動運転システムでは走行が難しから たが，現在ではこのような場所でも自動運転が十分可 能になってきている。

著者らの経験から，このような柔軟な自動運転が可 能になった理由は3つあると考えている。一番目の理 由は，コンピュータの処理能力の向上である。現在の コンピュータは一昔前のスーパーコンピュータのレベ ルまで進化していて, 従来車載装置としての演算が難 しかった大規模な計算がリアルタイムかつ省電力で実 現可能となってきている。二番目の理由は，人工知能 技術，いわゆる機械学習技術の発展がその要因となつ

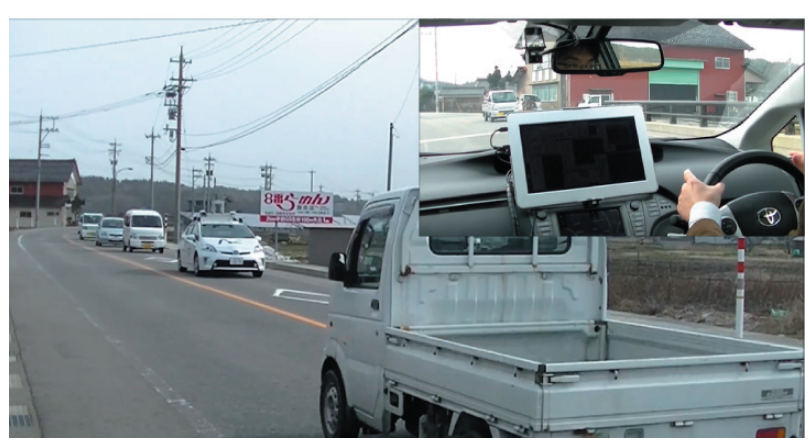

Fig. 1 Public road experiment on ordinary road. 


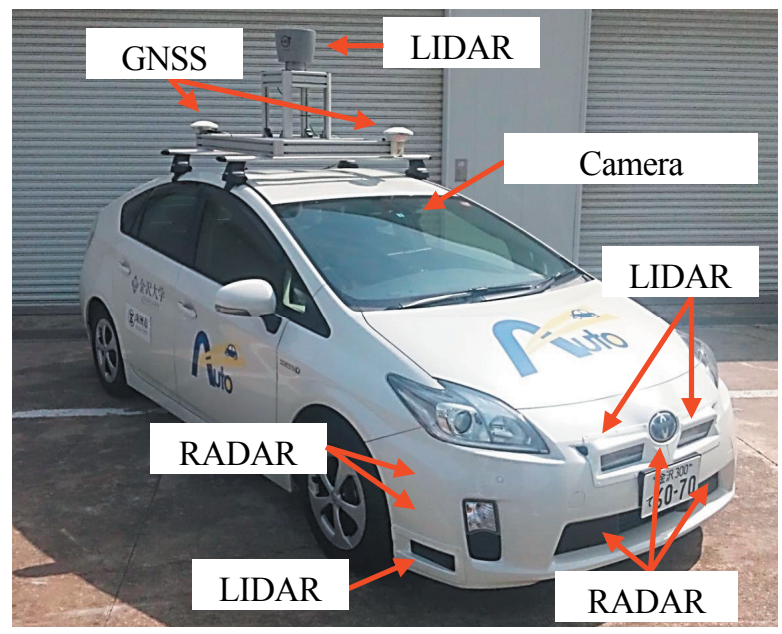

Fig. 2 Experimental vehicle equipped with many sensors.

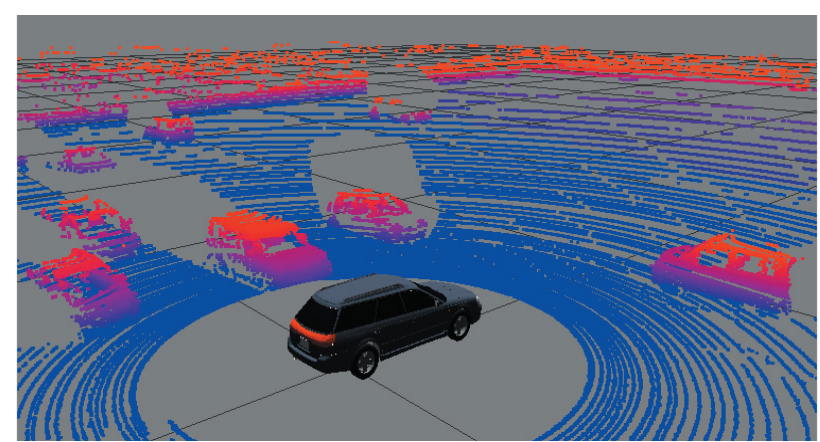

Fig. 3 Example of point cloud obtained from LIDAR.

ている。特にここ数年の DNN（Deep Neural Network） に関連した技術の発展は目覚ましく, 従来は認識が難 しいと思われていたことが今の技術では比較的簡単に 認識が可能となってきている。またそれに伴って，複 杂倠な状況判断を行いながら柔軟な自動運転を実現する ことが可能となってきている。そして最後の理由が高 精度地図の活用[6]である。従来の自動運転システムで は，道路にコストをかけて，八ード的なインフラを整 備することによって自動運転の難易度を下げる試みが 多く行われてきたが，現在では地図というソフトイン フラにコストをかける形へと発想が大きく変わってき ている。この場合，例えば著者らの取り組みのように 地方の一般道であってもその場所の高精度地図を用意 さえすれば柔軟に自動運転を行うことが可能となる。 これらの 3 つの技術革新によって, 現在の自動運転シ ステムでは高速道路以外の一般道を含め, 様々な自動 運転が実現可能となってきている。

本稿では，この近年話題となっている自動運転シス テムに必要となる技術の概要について述べる。また， 著者らの大学が実施中の公道走行実験の概要について 述べる。

\section{2 自動運転に必要な技術}

著者らの研究室では, 1998 年ごろから約 20 年間市 街地での走行を目指した自動運転システムの開発を行 つてきた。この間，自動運転機能に関する様々な技術 開発を行い, 複数の試験車両も構築してきた。現在主 に使用しているのが 4 台目の試験車両で, Fig. 2 に示 すように，複雑な周辺環境を認識するため多数のセン サが設置されている。メインのセンサとして使用して いるのが，車両上部に設置した Velodyne 社製の LIDAR(Light Detection and Ranging)である。Fig. 3 はこ の LIDAR を用いて周辺空間を計測した結果を示して いる。Fig. 3 に示すように, LIDAR はレーザ光線を様々 な方向に照射することで周辺環境の 3 次元的な距離分 布(ポイントクラウド)を取得することが可能となって いる。その他にも試験車両のバンパ内には 9 台のミリ 波レーダ(富士通テン社製)，6 台の LIDAR(IBEO 社製) 等が設置されている。またその他にも，カメラや GPS アンテナなど様々なセンサが設置されており，これら の 20 台近くのセンサを使用することで自動運転に必 要な認知機能を実現している。

自動運転システムではこのような様々なセンサを 駆使して周辺環境を認識し，その情報をもとに様々な 状況判断を行う必要がある。著者らの長年の取り組み から, 自動運転システムには周辺環境認識, 自己位置 推定, 走行軌道生成, ヒューマンマシンインターフェ 一スの 4 つの技術が必要であると考えている。下記に， これらの技術の概要について述べる。

\section{1 周辺環境認識[7]}

自動運転システムが障害物や周辺に走行する車や 自転車，歩行者といった様々な物体に衝突せずに走行 するためには，自車周辺の状況を正確に「認識」する 必要がある。ただ，よくよく考えてみるとこの「認識」 という言葉が非常にあいまいな言葉であり，実は「検 出」,「識別」,「予測」という 3 つの技術の総称である と考えている。

検出とは，周辺に存在する物体がどこに存在するの かを認識する技術であり，まさにセンサそのものの開 発に相当する。自動車は様々な日照条件や天候条件の もとで走行する必要があり，このような環境下におい ても確実に物体をとらえることが可能な技術開発が重 要な要素となる。一方, 例えば Fig. 2 に示すような大 


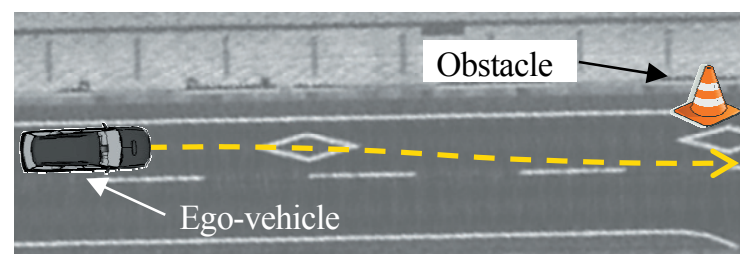

(a) Obstacle avoidance

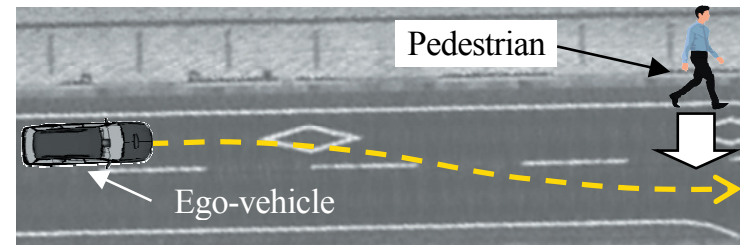

(b) Pedestrian avoidance

Fig. 4 Difference of avoidance behavior by object type.

量のセンサを搭載すれば自動運転が容易に実現できる かといえば，下記に述べる「識別」と「予測」という 2 つの技術が必要となるため, 実際には容易に自動運 転を実現することが難しい。

例えばLIDAR を用いると，Fig. 4 に示すように道路 脇に存在するコーンや歩行者といった「障害物」を容 易に検出することができる。このとき例えば人間が運 転をする場合であれば，障害物が歩行者である場合と そうでない場合にその回避の仕方を変化させるものと 考えられる。一方これらの物体の種別を「識別」せず に, 単に物体を「検出」するのみである場合, その物 体が何であったとしても単一の回避の仕方しか取れな くなってしまうため違和感のある走行となる。このた め, 物体種別を「識別」する技術が重要であるといえ る。例えば，Fig. 5 は Deep Neural Network を用いて画 像の各画素の意味を解析した例であり, 現在の技術を 用いると画像内の各領域に意味を持たせることが可能 となっている。このような識別に関する技術は，近年 の機械学習技術の進歩によってその能力が大きく向上 している。

最後に, 最も重要かつ困難な認識技術の要素が「予 測」である。自動車は高速で走行しているため, 衝突 せずに走行するためにはあらかじめ衝突する可能性を 予測して走行させる必要がある。一方, 車載センサに よって検出される情報は, あくまで計測した時点での 情報しか取得することができないため, 衝突したとき にはじめて「ぶつかった」という情報を取得できるこ ととなる。したがって, 時系列的に得られる過去のセ ンサ情報から未来の情報をいかに予測するかが重要な

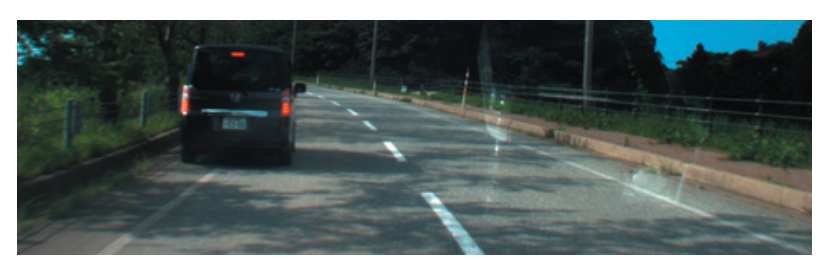

(a) Original image

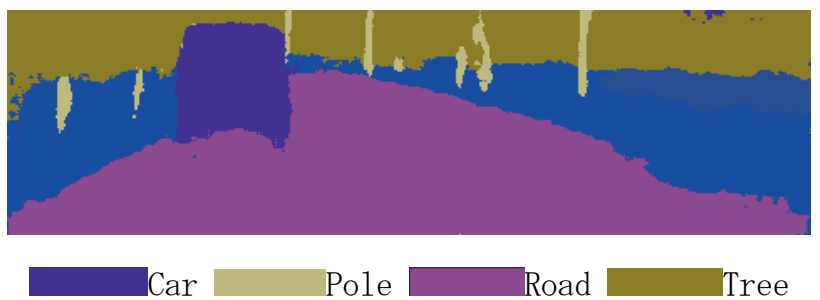

(b) Result of segmentation

Fig. 5 Semantic segmentation based on Deep Neural Network.

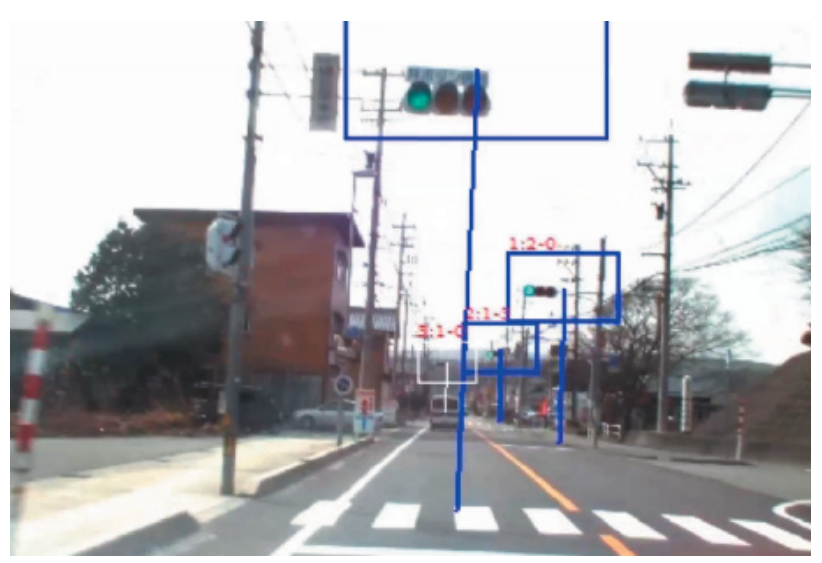

Fig. 6 Simultaneous recognition of plural traffic lights.

技術となる。

これらの検出，識別，予測という三つの技術が確立 されて初めて, 認識という技術が成り立つ。周辺環境 を「認識」すると一言で言っても, 実際には複雑な技 術の統合によってはじめて成立する技術であるといえ る。

その他, 市街地での走行では標識や信号機の認識も 必要となる。このうち標識に関しては, 制限速度や止 まれ標識など，多くの情報が時間的に変化のない情報 であるため，地図情報にこれらの情報を埋め込んでお くことでオンボードセンサによる認識を必ずしも行う 必要がないものもある。一方, 信号機や可変制限速度 標識のように時間的に変化する情報を提示しているも のに関しては, オンボードセンサでの認識が必要とな る。このような場合, 単なる提示情報の認識以外にも 様々な課題が存在している。例えば Fig. 6 は一般道の 交差点付近を自動走行中にオンボードカメラで画像を 
撮影し，信号機の認識をしている様子を示している。 この例では, 複数の信号機が 1 枚の画像中に同時に現 れている。このような場合, 認識した信号機がどの交 差点と意味として紐づいているのかを適切に判断でき ないと交差点への侵入判断自体ができなくなる。この ため, 単純に「認識」という機能を実現するだけでな く, 交通環境への意味の紐付を考慮した状況判断も必 要となる。

\section{2 自己位置推定}

自動運転に必要な技術の二つ目は自己位置推定で ある。1 章において, 近年の自動運転システムではソ フトインフラとして地図を活用することによって様々 な環境における自動運転が柔軟に行えるようになって きていると述べた。しかし，たとえ高精度な地図が用 意されていたとしても自動運転は容易には実現できな い。例えば人間が，土地勘のない場所で地下鉄に乗っ てある特定の目的地に訪問することを考える。この場 合, まず地下鉄の駅から地上に出た後, 手持ちの地図 と周辺の道路や建物といった情報をもとに自分が地図 上のどこにいてどちらを向いているのかを把握するで あろう。その後, 初めて現在位置から目的地まで進む 方向を把握して, 地図を用いて目的地まで到達すると いう行動をとると考えられる。実は地図を活用した自 動運転システムでもこれとほとんど同じ動作を行う必 要があるため, 自車が地図上のどこに存在しているの かを常に把握する技術が必要となる。

現在，日本国内では準天頂衛星が打ち上げられ，人 工衛星を用いた高精度な位置推定技術が比較的容易に 行えるようになってきている。しかし，例えばトンネ ルの中など人工衛星の電波を取得することが難しい環 境はたくさんある。このため, 人工衛星に頼らない自

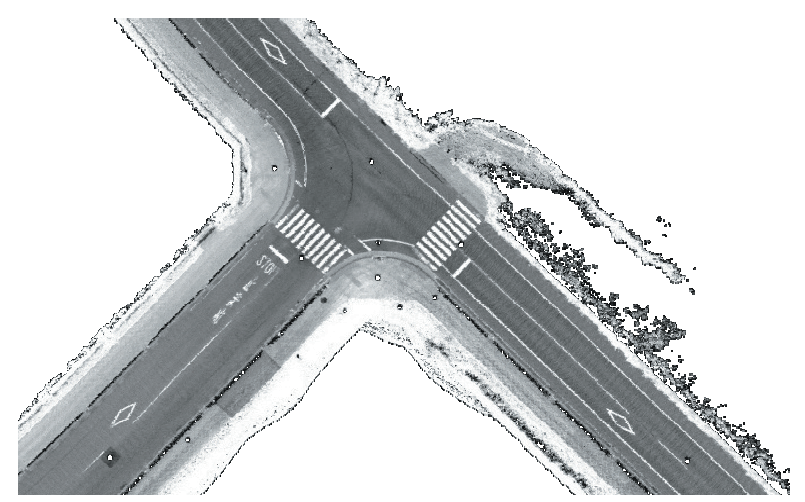

Fig. 7 Example of ortho-image used for localization.
己位置推定手法が必要となる[6]。一例として，著者ら の研究室では Fig. 7 に示寸ように道路を上空から見た 画像(オルソ画像)を地図として持たせておき，これを 用いて自己位置推定を行う方法を用いている。この場 合，人工衛星からの位置計測值を用いなくても，概ね $15 \mathrm{~cm}$ 程度の精度で自己位置を推定することが可能と なっている。

\section{3 走行軌道生成}

自動運転に必要な三つ目の技術は走行軌道生成（パ スプランニング）技術[8]である。パスプランニングで は, 主に目的地までの走行ルートの選択, 交通ルール への準拠，障害物の回避と先行車両追従といった項目 について検討する必要がある。

このうち走行ルートの選択に関しては, 概ねカーナ ビゲーションシステムで培われてきた技術を活用する ことができる。ただし，従来のカーナビゲーションシ ステムとは異なり, 複数車線ある道路のどの車線を走 行するのかという細かいレベルまでの計画を立てる必 要がある。

一方地図から選択した走行ルートは，あくまで目的 地までの道のりを表した経路情報にすぎないため，こ のルート上をどのように走行すべきかに関してはさら なる詳細検討が必要となる。例えば，走行ルート上に 一旦停止の交差点を右折寸る状況が発生した場合, 停 止線で一旦停止後, 交差点の左右から他車両が接近し ていないかどうかを確認し，安全が確認されれば交差 点へ侵入するといったいわゆる交通ルールや, 場合に よっては交通マナーといった観点で運転行動を適切に 管理しながら走行を行う必要がある。さらには，この ような交通ルールを守って走行するとしても，例えば 走行ルート上に存在する停止車両等の障害物へのハン ドルによる回避や先行車との車間距離を維持するため の速度制御など様々な状況を考慮する必要がある。

通常自動運転システムでは上記の複雑な運転行動 を適切に実施可能な軌道(走行経路と速度プロファイ ル)をオンボードセンサ情報や地図情報に基づき, リア ルタイムに生成する。そして, 最終的には生成された 軌道に対して精密に追従できるようにハンドル，スロ ットル,ブレーキを制御し, 必要に応じてウィンカー, ハザードを点滅させることで自動運転が実現される。 
2.4 ヒューマンマシンインターフェース

前節までに述べた技術を組み合わせると，自動車を 自動的に走行させることが可能となる。しかし実際の 自動車が道路を走行するためには常に車両内外の人間 とのコミュニケーションを図る技術(ヒューマンマシ ンインターフェース)が必要となる。

例えば車内の人とのコミュニケーションが必要な 例として, 普段自分が手動で運転している場所をたま たま自動運転で走行した場合を考えてみる。この場合, 自分がいつも通る道と違うルートを自動運転車が選択 する可能性があり, 自分が想像すらしていない交差点 を右左折する場合がある。このような場合，自動運転 車が何をしようとしているのかが分からないと, 搭乗 者が予期していない場所で交差点の右左折に伴う加減 速が突然起きてしまうため, その行動に不安になって しまう可能性がある。また, 車外の人とのコミュニケ ーションが必要な例として, 横断歩道がある。例えば 無人で走行する自動運転車両が横断歩道手前で停止を した場合を考える。このとき歩行者から見ると, 中に 運転者が存在していないため, 自動運転車は本当に自 分が横断歩道を渡るのを待機してくれるのかどうかが 不安になる可能性がある。

このように, 自動運転自動車が何を考え, 何をしよ うとしているのかを適切に車両内外の人への提示し, 人間に対する安心感を与えるヒューマンマシンインタ ーフェースも, 実際の自動運転には重要な技術の 1 つ であると考えられる。

\section{3 自動運転自動車の公道走行実験}

最後に, 著者らの研究室が実施中の公道走行実証実 験の概要について述べる。

著者らの研究室では，前章までに述べてきた技術や， 自動運転に必要な地図生成技術を含め, 様々な技術を 約 20 年にわたって開発を続けてきた。この過程では, 大学構内の駐車場や構内道路を用いた走行実験や, 自 動車学校のテストコースを活用した走行実験等を実施 してきた。特に自動車学校のテストコース内には様々 な交通環境が存在しているため, いわゆる交通ルール に相当するパスプランナの設計を行う際には大変重要 な過程であった。そして現在では，これらの成果をも とに日本国内の様々な公道で走行実証実験を行ってい る。

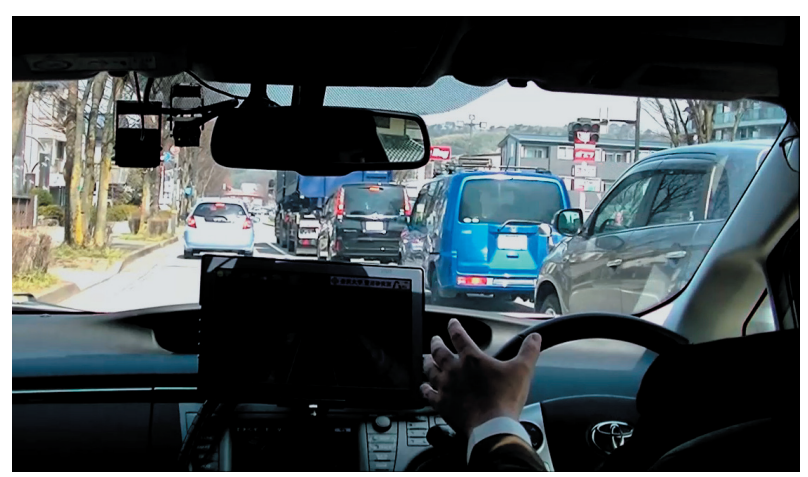

Fig.8 Autonomous driving in Kanazawa city with heavy traffic.

公道走行実験を最初に実施した場所は石川県珠洲 市である。石川県珠洲市は, 著者らの大学がある石川 県に存在する能登半島の先端に位置しており，人口が 約 1 万 5 千人程度の自治体である。このうち 65 歳以上 の高齢者の人口の割合が既に $46 \%$ を超えており, 高齢 化，過疎化が深刻な課題となっている。このような背 景から生じる交通に関する諸問題の解決を目的として, 自動運転自動車の実証実験を 2015 年 2 月 24 日から開 始している[5]。

実験開始当初は, 珠洲市内の病院が存在する市街地 や，山間部等を含む約 $6.6 \mathrm{~km}$ の特定のルートを走行し ており, このルートの走行から生じる様々な問題につ いて検討を行っていた。たとえば市街地部であれば, 信号機の有無や様々な交差点形状など, 多種多様な交 差点が存在している。また様々な車両, 自転車, 歩行 者といった交通参加者の挙動など, テストコースでは 得られない様々な状況が発生し，これらの環境で適切 な状況判断を行うための認識手法の検討やセンサレイ アウトの検討, パスプランナの設計等が重要なテーマ となっていた。また, 山間部であれば GPS や携帯の電 波環境の悪い中での走行なども検討課題の一つであつ た。そして現在では, 概ねこれらの問題が解決されつ つあり，珠洲市内のほぼ全域となるトータル $60 \mathrm{~km} の$ 道で走行実験(2015 年 10 月 )を行っている。

さらに現在では，例えば Fig. 8 に示すように多数の 車両が存在している街中での自動運転システムの動作 検証を目的として著者らの大学が存在する金沢市内の 街中での走行実験(2016 年 5 月 )や, 冬季における様々 な天候下での走行実験を目的として北海道網走市での 走行実験(2016 年 12 月 ) も行っている。 


\section{4 まとめ}

本稿では，近年さまざまな場所で話題となっている 自動運転システムに関する技術概要と, 著者らの大学 が国内の大学で初の試みとして実施中の一般道での公 道走行実証実験の概要について述べた。

自動運転システムは近年のコンピュータ処理能力 の向上, 人工知能技術の進歩, 高精度地図の活用など によって大幅に能力が向上しており, 現在では市街地 を含め様々な場所で柔軟に走行することが可能となっ てきている。一方, 現状の自動運転システムではまだ さまざまな技術課題を抱えているのも確かである。

例えば，現在の自動運転システムでは様々なセンサ を用い，それらのセンサ情報を融合して信頼性のある 状況判断を行う場合がほとんどとなっている。これは, 個々のセンサ情報のみでは必ずしも十分な能力を発揮 できないので，それを補うために複数センサ情報が必 須であるためである。しかし，本来真に信頼性のある 自動運転を実現するためには, 個々のセンサのみでも 十分な能力を発揮している状態が必要であり, それら を組み合わせることにより信頼性のある状況判断を行 うシステムを構築すべきであると考えられる。このた め, 個々のセンサのさらなる能力向上といった根本的 な部分での能力改善も必要となる。

また，自動車が走行する環境は雨や雪などの様々な 状況が存在している。現在の自動運転システムでは, 概ね雨が降っていたとしても自動運転を継続すること はもちろん可能ではあるが, 大雨の場合や, 雪が降っ ている場合では自動運転を継続することが難しい。こ のため, このような状況下でも適切に状況判断ができ るシステム設計も必要となる。

さらには, 技術的課題以外にも法律的な課題, 社会 受容性に関する課題, 新しい保険制度の確立など多岐 にわたる課題が存在しており, その社会導入には多く の検討が必要となる。一方, 自動運転システムには交 通事故の削減, 移動の快適性, 公共交通不足の解消な ど大きな期待が寄せられており, その社会導入が切望 されている。このため, 今後も自動運転システムの技 術開発とともに様々な分野の専門家との連携を図りつ つ, 自動運転システムの社会導入を進める検討を積極 的に進めることが重要であると考えられる。

\section{謝辞}

本研究の一部は総務省 戦略的情報通信研究開発推
進事業（SCOPE）地域 ICT 振興型研究開発「自動運転 車の地域振興 一活用に向けた研究開発 (No.152305001)」, 文部科学省 科学研究費補助金 基盤 研究 (B)「市街地交差点における自然な走行を実現可 能な完全自動運転システムの開発」等による成果を活 用して行われた研究である。

\section{参考文献}

[1] 津川定之, 自動運転システムの 60 年, 計測と制御, Vol.54, No.11, pp.789-802, 2015.

[2] 青木啓二, 森田康裕, 自動運転・隊列走行システムの開 発(第 1 報), 自動車技術会学術講演会 講演予稿集, No.94-09, pp.1-4, 2009.

[3] 水間毅, IMTS の安全性評価について, 電子情報通信学 会技術研究報告, DC2003-89, pp.75-80, 2003.

[4] 毛利宏, 白土良太, 古性裕之, 画像処理による車線追従 制御の検討, 電子情報通信学会技術研究報告. Vol.101, No.285, pp.55-60, 2001.

[5] 菅沼直樹, 林悠太郎, 永田大記, 高橋謙太, 高齢過疎地 域における自動運転自動車の市街地公道実証実験概要, 自動車技術会学術講演会講演予稿集, No,14-15S, pp.390-394, 2015.

[6] 菅沼直樹, 米陀佳祐, 自動車の自動運転におけるデジタ ル地図の活用, 日本ロボット学会誌, Vol.33, No.10, pp.760-765, 2015.

[7] 菅沼直樹, 米陀佳祐, 自動車の自動運転システムにおけ る交通環境認識, 自動車技術, Vol.71, No.2, pp.42-47, 2017.

[8] 菅沼直樹, 米陀佳祐, 自動運転自動車のパスプランニン グ，情報処理，Vol.57, No.5, pp.446-450, 2016. 